\title{
PRAKTIK MANAJEMEN MUTU TERPADU DAN HUBUNGANNYA DENGAN FORMALISASI, DESENTRALISASI, KUALITAS PRODUK, SERTA KINERJA ORGANISASI
}

\author{
Andre Dwijanto Witjaksono \\ dwiyan23@yahoo.co.id \\ Fakultas Ekonomi Universitas Negeri Surabaya
}

\begin{abstract}
The general objective of this study was to examine dan to analyze the relationship of total quality management practice with formalization, decentralization, product quality, dan organization performance. To reach the objective, this study was carried out by using survey research. Samples, recruited by means of sampling population, consisted of 162 four or more wheel automotive company producing part dan equipment in Indonesia. 31 responses returned were analyzed with partial least square model to find out the relationship among variables simultaneously. The findings of this study indicate that: 1. Formalization have influence on the $T Q M$ Practice, 2. Decentralization does not have influence on the TQM Practice, 3. TQM Practice has influence on Product Quality, 4. Product quality has influence on organization performance, 5. TQM Practice has influence on the organizational performance. Based on the findings of the study, it can be concluded that TQM Practice was proven as a powerful approach for the organization which desired to accomplish high product quality dan excellent performance. The findings also indicated that automotive part dan equipment industries in Indonesia still have low technology knowledge, dan tend to centralized structure.
\end{abstract}

Keywords: Formalization, decentralization, TQM Practice, product quality, organization performance

\begin{abstract}
ABSTRAK
Tujuan umum dari penelitian ini adalah untuk mempelajari dan menganalisis hubungan dari praktik manajemen mutu terpadu (total quality management) dengan formalisasi, desentralisasi, kualitas produk, dan kinerja organisasi. Untuk mencapai tujuan tersebut, penelitian ini dilakukan dengan menggunakan penelitian survei. Sampel, direkrut melalui populasi sampling, terdiri dari 162 empat atau lebih bagian roda perusahaan otomotif memproduksi dan peralatan di Indonesia. Hanya 31 tanggapan yang dikembalikan dan dinyatakan layak untuk kemudian dianalisis dengan model partial least square untuk mengetahui hubungan antar variabel secara bersamaan. Temuan penelitian ini menunjukkan bahwa: 1. Formalisasi berpengaruh terhadap Praktik TQM, 2. Desentralisasi tidak berpengaruh terhadap Praktik TQM, 3. Praktik TQM mempunyai pengaruh signifikan terhadap Kualitas Produk, 4. Kualitas produk berpengaruh terhadap kinerja organisasi, 5. Praktik TQM berpengaruh terhadap kinerja organisasi. Berdasarkan temuan penelitian, dapat disimpulkan bahwa praktik TQM terbukti sebagai pendekatan yang kuat bagi organisasi yang menginginkan untuk mencapai kualitas produk tinggi dan kinerja yang sangat baik. Hasil temuan juga menunjukkan bahwa industri perlengkapan dan komponen otomotif roda empat atau lebih di Indonesia masih memiliki pengetahuan teknologi yang relatif rendah, dan cenderung memiliki struktur terpusat (sentralisasi).
\end{abstract}

Kata kunci: Formalisasi, desentralisasi, praktik TQM, kualitas produk, kinerja organisasi

\section{PENDAHULUAN}

Teori institusional (kelembagaan) adalah sebuah teori yang mempelajari bagaimana organisasi dapat meningkatkan kemampuannya untuk bertumbuh dan bertahan dalam suatu lingkungan persaingan, de- ngan cara memuaskan stakeholder mereka (Jones, 2004). Pelanggan, karyawan, atau semua kelompok yang mengendalikan pasokan sumberdaya yang terbatas, merupakan stakeholder organisasi. Menurut teori ini, pengertian institusi atau kelembagaan 
bukan dalam arti fisik, tetapi dalam pengertian mengenai nilai-nilai, regulasi, norma, kebiasaan atau budaya, yang semuanya terefleksi dalam kegiatan ekonomi. Organisasi mungkin dipaksa untuk mengubah struktur organisasinya karena adanya tekanan regulasi pemerintah, politik, norma, dan budaya; atau meniru struktur maupun strategi dari organisasi yang lain sebagai hasil tekanan persaingan (Wagner et al., 2001). Adopsi Total Quality Management (TQM) merupakan salah satu bentuk tindakan untuk meniru struktur atau strategi dari organisasi yang lain sebagai hasil tekanan persaingan.

Manajemen mutu terpadu sebagai filosofi manajemen modern, telah menjadi konsep yang banyak digunakan, menghubungkan perusahaan pada penekanan terhadap mutu dengan pendekatan hubungan yang lebih luas dalam suatu industri. Dinyatakan pula bahwa pendekatan TQM menempatkan tanggung jawab untuk kualitas produk atau jasa secara langsung ke dunia kerja. Selain kajian manajemen menyeluruh, MMT disertai dengan pembicaraan banyak tentang filsafat, misi, kepemimpinan, orientasi pelanggan, dan tujuan zerodefects adalah tema utama dalam TQM (Shahraki et al., 2011). Senada dengan pengertian di atas, MMT juga mampu memaksimumkan daya saing organisasi (Nasution, 2005). Meskipun demikian, tidaklah mudah menerapkan MMT. Keberhasilan penerapan MMT memerlukan waktu yang tidak singkat, dan ada kalanya manajer kurang peduli dengan penerapan MMT di perusahaannya. Bagaimanapun, waktu dan sumber daya manusia merupakan faktor penting dalam keberhasilan penerapan MMT (Psychogios and Priporas, 2007).

Dalam studi ini, analisis mengenai praktik manajemen mutu dilakukan pada industri manufaktur yang bergerak dalam bidang otomotif roda empat atau lebih (khususnya industri perlengkapan dan komponen). Industri ini dipilih karena beberapa alasan. Tekanan persaingan yang kuat telah memaksa banyak perusahaan manufaktur untuk meraih MMT secara aktif agar tetap bertahan dan berhasil dalam bisnis. Untuk itu, TQM seharusnya dibangun dengan baik dalam sektor manufaktur. Alasan yang lain adalah bahwa teoriteori tentang manajemen mutu, seperti TQM, just in time, kanban system, six sigma, dan TPM (total productive maintenance), banyak yang muncul melalui penelitian dari industri manufaktur, terutama otomotif atau komponen otomotif seperti Toyota, Nippondenso, atau industri manufaktur yang lain, seperti Motorola, Xerox, dan sebaginya. Selain itu, Kamar Dagang dan Industri Indonesia (KADIN) telah menetapkan industri otomotif dan komponen otomotif sebagai salah satu klaster industri unggulan pendongkrak pertumbuhan ekonomi (Kamar Dagang dan Industri Indonesia, 2007).

Perkembangan industri otomotif tidak diikuti oleh pertumbuhan industri komponen otomotif di Indonesia. Hal ini terlihat dari cukup banyaknya industri otomotif berkelas dunia yang menjadikan Indonesia menjadi basis produksi, antara lain: Ford Motor Company, yang telah menyiapkan investasi Rp 12.6 triliun untuk mendirikan pabrik di Indonesia (Jawa Pos, 22 Mei 2006). Demikian pula produsen asal Asia seperti Proton (Malaysia) menginvestasikan dananya di Indonesia sebesar Rp 250 miliar, Nissan (Jepang) sebesar USD 70 juta, dan Hyundai (Korea Selatan) sebesar USD 23 juta, dan tampaknya juga akan diikuti oleh beberapa produsen besar lainnya. Di sisi lain, pertumbuhan industri otomotif di Indonesia tampak tidak diimbangi dengan tumbuhnya industri pendukung. Pada tahun 2003, jumlah industri komponen baru mencapai 250 perusahaan dengan kompo sisi perusahaan 80 persen bergerak di komponen roda dua dan 20 persen komponen roda empat (tidak termasuk perusahaan penghasil perlengkapan). Berdasarkan data Gabungan Industri Alat Mobil dan Motor, revenue industri komponen cenderung menurun (lihat Tabel 1). Jika dibandingkan 
dengan Thailand yang merupakan pesaing Indonesia dalam sektor otomotif, negara itu mempunyai sekitar 1.709 perusahaan komponen dengan 709 perusahaan sebagai pemasok komponen original untuk perusahaan perakitan atau OEM (Original Equipment Manufacturing) dengan perincian 386 sebagai pemasok untuk kendaraan roda empat, 201 perusahaan untuk roda dua dan 122 perusahaan memasok sekaligus untuk keduanya. Total revenue Thailand pada tahun 2001 saja, mampu mencapai US\$ 5 miliar, sedangkan Indonesia pada tahun 2002, hanya US\$ 14,1 juta US\$.

\section{TINJAUAN TEORETIS}

Perkembangan manajemen mutu terpadu (MMT) telah mengalami perjalanan yang panjang. Penerapan MMT ternyata tidak selamanya berhasil, tetapi terdapat pula yang mengalami kegagalan (Sebastianelli and Tamimi, 2003). Fenomena ini kemudian memicu berbagai penelitian yang dikaitkan dengan implementasi MMT, dalam hubungannya dengan faktor-faktor yang lain (Ahire et al., 1996; Germain dan Spears, 1999; Brah et al., 2002; Claycomb et al., 2002; Costa dan Lorente, 2004a dan 2004b; Jabnoun, 2005; Parncharoen et al., 2003; Prajogo dan Brown, 2004; Sila dan Ebrahimpour, 2002; Sila, 2007; Thamizhmanii and Hasan, 2010; Wagner et al., 2001).

Dalam berbagai literatur, manajemen mutu merupakan fungsi organisasi yang luas dan membutuhkan teori organisasi untuk tujuan penjelasan ataupun prediksinya Lebih lanjut dikatakan Robbins (2003), bahwa struktur organisasi dapat dilihat melalui bagaimanakah tugas-tugas pekerjaan dalam sebuah organisasi dibagi secara formal, dikelompokkan, dan dikoordinasikan. Beberapa di antaranya formalisasi, dan desentralisasi/sentralisasi.

Formalisasi menyatakan tingkat di mana pekerjaan di dalam organisasi telah terstandarisasi (Robbins, 2003). Jones (2004) menyatakan bahwa operasionalisasi pekerjaan yang terstandarisasi adalah berupa aturan dan prosedur yang tertulis (terdeskripsikan). Sentralisasi mengacu pada tingkat dimana pengambilan keputusan dipusatkan pada posisi tertentu dalam organisasi (Robbins, 2003). Semakin besar pemusatan pengambilan keputusan pada posisi tertentu pada manajemen level atas berarti semakin tersentralisasi organisasi itu. Semakin rendah tingkat sentralisasi maka semakin tinggi tingkat desentralisasi.

Dalam sebuah organisasi perusahaan manufaktur, kualitas produk adalah salah satu dari empat hal yang menjadi kunci keunggulan bersaing selain harga, keandalan sebagai pemasok, dan ketepatan waktu pengiriman.

Garvin (dalam Nasution, 2005) menyata kan bahwa terdapat sembilan dimensi untuk mengukur kualitas produk, antara lain: performa, keistimewaan, keandalan,

Tabel 1

Perbandingan Revenue Industri Komponen Otomotif Indonesia dan Thailand Tahun $2000-2002$

\begin{tabular}{lcccc}
\hline \hline \multicolumn{2}{c}{ Indonesia } & & Thailand \\
\hline & 2000 & 2001 & 2002 & 2001 \\
\hline Penj. Dometik & US\$ 15,6 juta & US\$ 13,7 juta & US\$ 13,4 juta & US\$ 3,6miliar \\
Ekspor & US\$613.000 & US\$ 681.000 & US\$ 629.000 & US\$ 1,4 miliar \\
Total & US\$ 16,2 juta & US\$ 14,4 juta & US\$ 14,1 juta & US\$ 5 miliar \\
\hline
\end{tabular}

(Sumber: Siagian, 2004; data diolah) 

konformansi atau tingkat kesesuaian, daya tahan, kemampuan pelayanan, estetika, dan kualitas yang dipersepsikan, yang kesemuanya ini berorientasi kepada pelanggan. Manajemen mutu terpadu (total quality management) merupakan suatu pendekatan yang berusaha memaksimumkan daya saing organisasi melalui perbaikan terus menerus atas produk, tenaga kerja, proses, dan lingkungannya (Nasution, 2005).

Kondisi yang sering terjadi kini adalah bahwa pelaksanaan MMT banyak timbul masalah dan situasi standar yang diselesaikan secara sementara. Di samping itu sistem manajemen yang ada kurang transparan dan bersifat formal atau memiliki formalisasi yang tinggi (Thamizhmanii and Hasan, 2010). Berkaitan dengan konstruk MMT, telah dilakukan dalam berbagai studi sebelumnya (Ahire et al., 1996; Thamizhmanii dan Hasan, 2010).

Dalam studi yang dilakukan oleh Jabnoun (2005), dilakukan analisis faktor dari tujuh dimensi termasuk jaringan proses, struktur mekanistik, struktur klasik, formalisasi, penghindaran risiko, struktur organik, dan kompleksitas. Hasil menunjukkan bahwa dimensi jaringan proses dan struktur organik mendukung pelaksanaan berorientasi pelanggan TQM, sementara penghindaran risiko, struktur mekanistik, dan kompleksitas menghambat itu. Parncharoen et al. (2003), meneliti pengaruh desain organisasi terhadap keberhasilan implementasi MMT pada perusahaan manufaktur dan jasa, serta membandingkan antara perusahaan dengan kepemilikan orang Australia dengan Thailand. Hasil penelitian menyatakan bahwa desain organisasi memiliki efek signifikan pada keberhasilan MMT, di mana formalisasi memiliki pengaruh positif terhadap keberhasilan MMT, sedangkan sentralisasi memiliki pengaruh negatif terhadap keberhasilan MMT.

Evans dan Jack (2003) dalam salah satu hipotesisnya membuktikan adanya pengaruh yang signifikan antara kualitas produk terhadap kinerja keuangan. Beberapa pene- litian yang lain mengungkapkan adanya hubungan antara praktik MMT dengan kinerja organisasi/bisnis termasuk didalamnya kinerja finansial maupun non finansial (Claycomb et al., 2002; Brah et al., 2002; Fynes dan Voss, 2001; Prajogo dan Brown, 2004).

Berdasarkan pemikiran-pemikiran di atas serta didukung penelitian empiris yang telah diuraikan sebelumnya, masih belum ada pengujian secara komprehensif yang melibatkan praktik manajemen mutu terpadu pada industri perlengkapan dan komponen kendaraan roda empat atau lebih di Indonesia yang dihubungkan dengan komponen struktur organisasi (desentralisasi dan formalisasi), kualitas produk, dan kinerja organisasi sekaligus.

Tujuan dari penelitian ini adalah menguji dan menganalisis : 1) pengaruh formalisasi terhadap praktik MMT; 2) pengaruh desentralisasi terhadap praktik MMT; 3) pengaruh praktik MMT terhadap kualitas produk ; 4) pengaruh kualitas produk terhadap kinerja organisasi; dan 5) pengaruh praktik MMT terhadap kinerja organisasi.

\section{METODE PENELITIAN}

Metode yang digunakan dalam studi ini adalah metode survei, yaitu studi yang dilakukan dengan mengambil sebagian populasi sebagai sampel atau keseluruhan unit dalam populasi untuk diteliti melalui pengajuan pertanyaan untuk memperoleh tanggapan atau jawaban dari subyek yang diamati. Data yang dihasilkan dapat berasal dari wawancara ataupun kuisioner sebagai instrumen pengumpulan data.

Berdasarkan kemampuan peneliti untuk memberikan dampak terhadap variabelvariabel yang diteliti, maka studi ini tergolong ex post facto, karena tidak bersifat eksperimental dan lingkungan penelitiannya dilakukan di lapangan, bukan laboratorium. Studi ini juga bermaksud untuk memberikan penjelasan hubungan kausalitas antar variabel melalui pengujian hipotesis, maka sifat dari studi penelitian ini adalah explanatory research. Jenis penelitian 
ini untuk mengetahui dan menjelaskan pengaruh antar variabel yang ada dan dilanjutkan dengan pengujian hipotesis.

Populasi dalam studi ini adalah industri manufaktur yang bergerak di bidang otomotif, khususnya industri perlengkapan dan komponen kendaraan bermotor roda empat atau lebih di Indonesia, yaitu sebanyak 162 perusahaan. Mengingat jumlah populasinya hanya sebesar 162 , maka setiap unit analisis dalam populasi ini akan turut dianalisis, sehingga merupakan studi sensus, dan tidak dilakukan pengambilan sampel.

Terdapat 16 Indikator dalam mengukur formalisasi dan 4 indikator untuk mengukur desentralisasi yang diadopsi dari Germain dan Spears (1999). Untuk mengukur dimensi praktik MMT dikembangkan dari 5 item pengukuran Ahire et al. (1996), serta 2 item dari Fynes dan Voss (2001). Dalam mengukur kualitas produk digunakan 4 indikator yang dikembangkan dari Garvin (dalam Nasution, 2005), sedangkan kinerja organisasi diukur berdasarkan 9 item indikator yang diadopsi dari Costa dan Lorente (2004a, 2004b).

Instrumen utama dalam studi ini adalah kuisioner yang ditujukan kepada pimpinan perusahaan dan general manager. Apabila pimpinan perusahaan atau general manager berhalangan, maka diharapkan isian daftar pertanyaan akan dijawab oleh manajer dengan tingkatan minimal sebagai manajer divisi.

Data dalam studi ini dikumpulkan dengan dua cara, yaitu dengan mendatangi langsung (untuk wilayah Jawa Timur), dan dengan cara mengirimkan kuisioner kepada responden melalui surat yang bebas perangko. Kuisioner disebarkan sebanyak perusahaan dalam industri perlengkapan dan komponen kendaraan bermotor roda empat atau lebih, yaitu 162 perusahaan, di mana pada setiap unit analisis akan diberikan daftar pertanyaan terhadap responden dengan jabatan minimal sebagai manajer divisi, sampai dengan general manager atau pimpinan perusahaan jika memungkinkan.
Tingkat pengembalian kuisioner adalah sebesar $19,14 \%$ atau 31 perusahaan yang bersedia dan dinyatakan layak sebagai unit analisis, sehingga digunakan analisis PLS (partial least square), karena PLS tidak memerlukan ukuran sampel yang besar (antara 30-100). PLS (partial least square) merupakan alternatif dari analisis structural equation model (SEM) yang selama ini dikenal, namun berbasis komponen atau varians. PLS bersifat non parametrik yang tidak terikat asumsi data harus berdistribusi normal secara multivariat atau diperlukannya jumlah sampel yang besar (Ghozali, 2006).

Dalam studi ini dilakukan sejumlah pengujian untuk mereduksi kemungkinan terjadinya bias, yaitu melalui uji homogenitas dan uji bias non respon. Sebagaimana pengujian peluang munculnya bias dari data yang dihasilkan, menurut Costa dan Lorente (2004a), size (ukuran perusahaan) seringkali memberikan efek bias dalam meyimpulkan sebuah analisis hasil studi.

Menurut BPS (Badan Pusat Statistik), kriteria ukuran perusahaan dapat dilihat dari jumlah tenaga kerja (BPS Provinsi Jawa Timur, 2004), di mana perusahaan skala besar adalah perusahaan yang memiliki jumlah tenaga kerja 100 orang ke atas, sedangkan perusahaan skala sedang adalah yang memiliki jumlah tenaga kerja dari 2099 orang. Pengujian dilakukan dengan cara membandingkan skor seluruh variabel eksogen antara ukuran perusahaan yang berbeda dengan uji $t$. Jika nilai signifikansi melebihi 5\%, maka dapat disimpulkan bahwa kedua populasi homogen.

Pengujian berikutnya adalah menguji non response biased dengan cara membandingkan mean dari pengambilan data pada survei yang pertama dengan data pada survei yang kedua. Responden yang masuk dalam kategori pertama adalah responden yang mengembalikan kuisioner dalam waktu yang tidak terlalu lama (kurang dari tiga bulan dan selanjutnya disebut kelompok respon). Responden ini 
mengindikasikan kemauan atau kesediaan yang antusias dalam mengirimkan kembali jawaban kuisioner. Responden yang masuk dalam kategori kedua adalah responden yang memberikan tanggapan setelah pengiriman kuisioner tahap kedua, di mana sebelumnya tidak memberikan tanggapan pada tahap pertama (selanjutnya disebut kelompok non respon).

Khusus untuk keperluan analisis konfirmatori, perkembangan teknik analisisnya telah berkembang sedemikian rupa, terutama dalam bidang psikologi, psikometrika, dan epidemologi. Hampir semua model dan teori yang diaplikasikan dalam bidang-bidang ini diformulasikan dalam bentuk konstruk hipotetikal yang juga memiliki istilah lain variabel laten, yang tidak bisa diukur atau diamati secara langsung akan tetapi harus diukur oleh variabel laten lain.

Analisis tradisional dalam menghitung variabel komposit terutama dengan skala data nominal/ordinal (polichoric) atau skala dikotomis (tetrachoric) memiliki risiko generalisasi yang bias (Rowe, 2006). Skala data kontinyu adalah data yang memiliki skala lebih besar dari 15, sedangkan jika kurang dari 15 maka dikategorikan sebagai data ordinal (Ghozali dan Fuad, 2005).
Untuk keperluan perhitungan sebuah variabel komposit, digunakan proportional weighted scale score yang turut menyertakan perhitungan ukuran kesalahan individual maupun gabungan, sehingga mampu mengonversi menjadi variabel kontinyu. Hasil ini akan menjamin perhitungan variabel komposit memiliki nilai yang sama dengan skala ukuran indikator. Untuk keperluan pengujian analisis secara keseluruhan digunakan software Smart PLS 1.0, Simplis (Lisrel 8.54), MS Excel 2003, dan SPSS 13.00.

Hipotesis yang diajukan adalah sebagai berikut:

$\mathrm{H}_{1}$ : Formalisasi berpengaruh signifikan terhadap praktik MMT.

$\mathrm{H}_{2}$ : Desentralisasi berpengaruh signifikan terhadap praktik MMT.

$\mathrm{H}_{3}$ : Praktik MMT berpengaruh signifikan terhadap kualitas produk.

$\mathrm{H}_{4}$ : Kualitas produk berpengaruh signifikan terhadap kinerja organisasi.

$\mathrm{H}_{5}$ : Praktik MMT berpengaruh signifikan terhadap kinerja organisasi.

Adapun model yang dibangun beserta penjelasan hipotesisnya adalah sebagai berikut (Gambar 1):

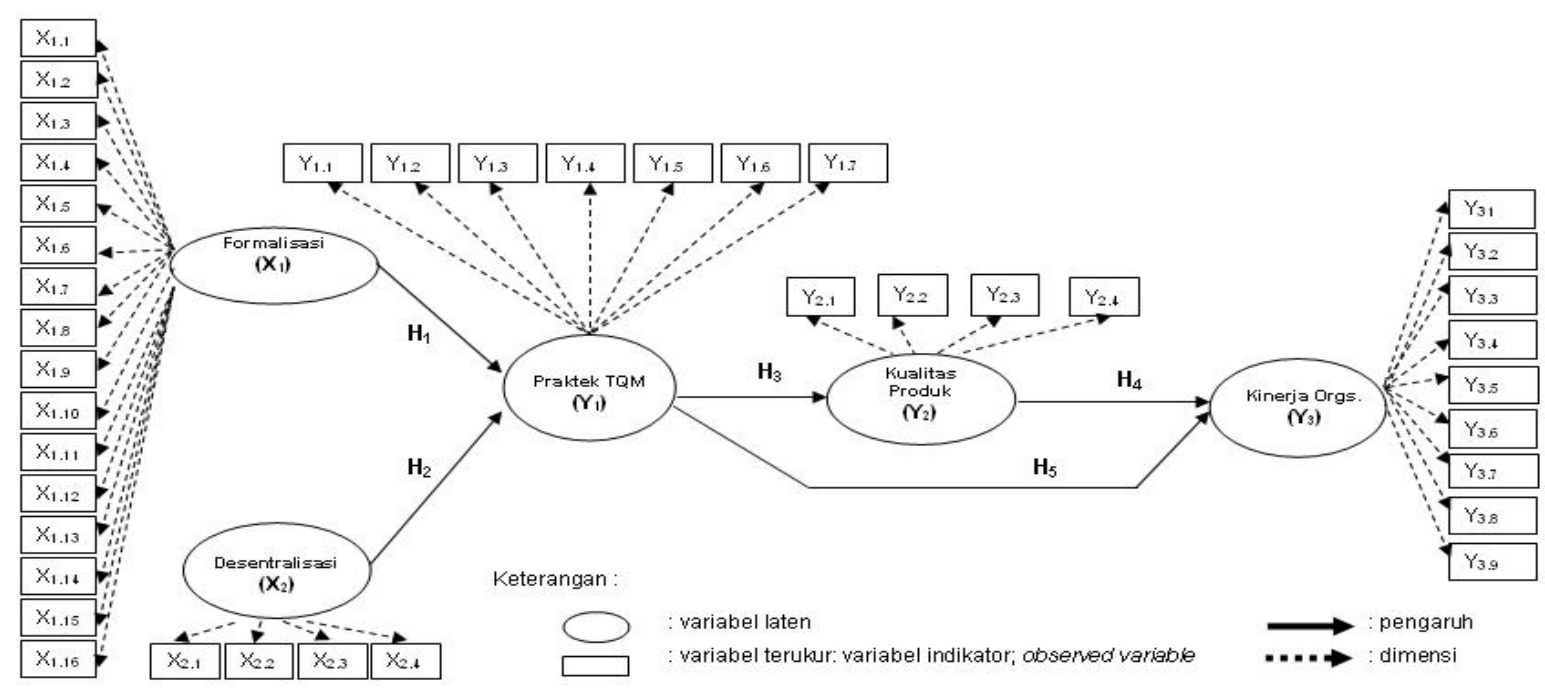

Gambar 1

Rerangka Koseptual Penelitian 
54 Ekuitas: Jurnal Ekonomi dan Keuangan - Volume 16, Nomor 1, Maret 2012 : 48-62

Tabel 2

Hasil Estimasi Outer Loadings

\begin{tabular}{|c|c|c|c|}
\hline & Factor Loading & T-Statistic & P-Value \\
\hline \multicolumn{4}{|l|}{ TFORM (X1) } \\
\hline x11 & 0,824 & 16,277 & 0,000 \\
\hline x110 & 0,946 & 58,351 & 0,000 \\
\hline x111 & 0,900 & 29,109 & 0,000 \\
\hline x112 & 0,876 & 16,856 & 0,000 \\
\hline x113 & 0,881 & 19,292 & 0,000 \\
\hline x114 & 0,893 & 18,450 & 0,000 \\
\hline x115 & 0,879 & 29,943 & 0,000 \\
\hline x116 & 0,909 & 43,991 & 0,000 \\
\hline$x 12$ & 0,761 & 9,234 & 0,000 \\
\hline$x 13$ & 0,915 & 41,863 & 0,000 \\
\hline x14 & 0,915 & 35,675 & 0,000 \\
\hline x15 & 0,870 & 17,452 & 0,000 \\
\hline x16 & 0,818 & 13,533 & 0,000 \\
\hline$x 17$ & 0,848 & 13,752 & 0,000 \\
\hline x18 & 0,898 & 32,339 & 0,000 \\
\hline x19 & 0,915 & 28,845 & 0,000 \\
\hline \multicolumn{4}{|l|}{ TDES (X2) } \\
\hline$x 21$ & 0,929 & 15,280 & 0,000 \\
\hline$x 22$ & 0,866 & 15,313 & 0,000 \\
\hline$x 23$ & 0,978 & 40,629 & 0,000 \\
\hline$x 24$ & 0,968 & 24,268 & 0,000 \\
\hline \multicolumn{4}{|l|}{ TPMMT (Y1) } \\
\hline Fok_Pel (y12) & 0,929 & 28,544 & 0,000 \\
\hline MMP (y13) & 0,870 & 12,909 & 0,000 \\
\hline $\mathrm{MP}(\mathrm{y} 16)$ & 0,852 & 15,003 & 0,000 \\
\hline PBERD (y14) & 0,925 & 30,979 & 0,000 \\
\hline PELTHN (y15) & 0,922 & 33,203 & 0,000 \\
\hline PHRG (y17) & 0,681 & 8,256 & 0,000 \\
\hline TMC (y11) & 0,904 & 25,695 & 0,000 \\
\hline \multicolumn{4}{|l|}{$\mathrm{KP}(\mathrm{Y} 2)$} \\
\hline y21 & 0,869 & 13,946 & 0,000 \\
\hline y22 & 0,954 & 73,093 & 0,000 \\
\hline y23 & 0,897 & 25,700 & 0,000 \\
\hline y24 & 0,943 & 67,904 & 0,000 \\
\hline \multicolumn{4}{|l|}{ KINOR } \\
\hline y32 & 0,635 & 6,551 & 0,000 \\
\hline y33 & 0,719 & 10,404 & 0,000 \\
\hline y34 & 0,831 & 17,131 & 0,000 \\
\hline y36 & 0,807 & 16,910 & 0,000 \\
\hline y37 & 0,731 & 8,086 & 0,000 \\
\hline y38 & 0,788 & 18,289 & 0,000 \\
\hline y39 & 0,668 & 7,570 & 0,000 \\
\hline
\end{tabular}

Sumber: Data diolah 
Tabel 3

Nilai R-Square

\begin{tabular}{ccc}
\hline \hline Variabel & R-square & $\mathbf{Q}^{2}$ Redundancy \\
\hline T FORM & & \\
T DES & & \\
TPMMT & 0,562 & 0,427 \\
KUAL PRO & 0,499 & 0,420 \\
KINOR & 0,650 & 0,357 \\
\hline
\end{tabular}

Sumber: Data diolah

Tabel 4

Hasil Estimasi Inner Weights

\begin{tabular}{ccccc}
\hline \hline & Koefisien Jalur & T-Statistic & P-Value & Kesimpulan \\
\hline TFORM (X1) -> TPMMT (Y1) & 0,757 & 8,842 & 0,000 & Signifikan \\
TDES (X2) -> PMMT (Y1) & $-0,050$ & 0,486 & 0,629 & Tidak Signifikan \\
TPMMT (Y1) -> KP (Y2) & 0,707 & 10,542 & 0,000 & Signifikan \\
TPMMT (Y1) -> KINOR (Y3) & 0,287 & 2,899 & 0,006 & Signifikan \\
KP (Y2) -> KINOR (Y3) & 0,575 & 5,979 & 0,000 & Signifikan \\
\hline
\end{tabular}

Sumber: Data diolah

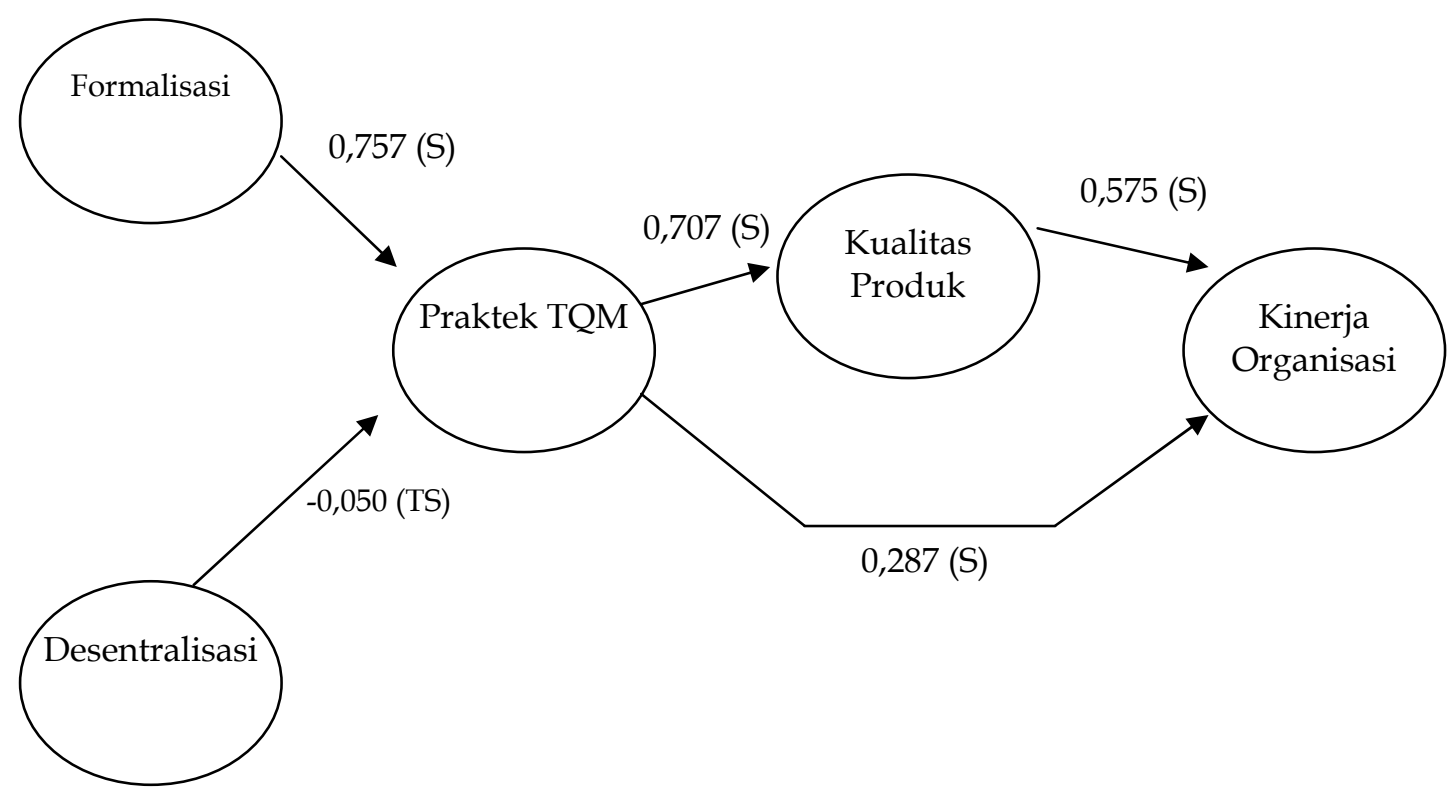

Keterangan: $\mathrm{S}=$ Signifikan, $\mathrm{TS}=$ Tidak Signfikan

Gambar 2

Pengaruh Antar Variabel Laten 
Tabel 5

Uji Non Response Bias

\begin{tabular}{|c|c|c|c|c|c|c|c|c|c|c|}
\hline \multicolumn{11}{|c|}{ Independent Samples Test } \\
\hline & & \multicolumn{2}{|c|}{$\begin{array}{l}\text { Levene's Test for } \\
\text { Equality of Variances }\end{array}$} & \multicolumn{7}{|c|}{ t-test for Equality of Means } \\
\hline & & \multirow[b]{2}{*}{$\mathrm{F}$} & \multirow[b]{2}{*}{ Sig. } & \multirow[b]{2}{*}{$t$} & \multirow[b]{2}{*}{$\mathrm{d}$} & \multirow[b]{2}{*}{ Sig. (2-tailed) } & \multirow{2}{*}{$\begin{array}{c}\text { Mean } \\
\text { Difference }\end{array}$} & \multirow{2}{*}{$\begin{array}{l}\text { Std. Error } \\
\text { Difference }\end{array}$} & \multicolumn{2}{|c|}{$\begin{array}{l}95 \% \text { Confidence } \\
\text { Interval of } \\
\text { Difference }\end{array}$} \\
\hline & & & & & & & & & Lowe & Uppe \\
\hline \multirow[t]{2}{*}{ TFORM } & $\begin{array}{l}\text { Equal variances } \\
\text { assumed }\end{array}$ &, 212 & ,649 & -161 & 29 &, 873 &,- 08433 &, 52304 & $-1,15407$ & ,98540 \\
\hline & $\begin{array}{l}\text { Equal variances } \\
\text { not assumed }\end{array}$ & & & -162 & 28,952 & 873 &,- 08433 &, 52117 & $-1,15032$ & ,98165 \\
\hline \multirow[t]{2}{*}{ TDES } & $\begin{array}{l}\text { Equal variances } \\
\text { assumed }\end{array}$ & ,444 &, 511 & , 126 & 29 & ,901 & ,05521 & ,43927 &,- 84321 & ,95363 \\
\hline & $\begin{array}{l}\text { Equal variances } \\
\text { not assumed }\end{array}$ & & & 127 & 27,680 & 900 & 05521 & ,43515 &,- 83662 & 94704 \\
\hline \multirow[t]{2}{*}{ TPTQM } & $\begin{array}{l}\text { Equal variances } \\
\text { assumed }\end{array}$ & 3,257 & ,082 &,- 978 & 29 &, 336 &,- 41179 & ,42118 & $-1,27320$ & ,44962 \\
\hline & $\begin{array}{l}\text { Equal variances } \\
\text { not assumed }\end{array}$ & & &,- 997 & 22,441 &, 329 & -,41179 & ,41289 & $-1,26710$ & 44351 \\
\hline \multirow[t]{2}{*}{ KP } & $\begin{array}{l}\text { Equal variances } \\
\text { assumed }\end{array}$ & 1,342 &, 256 & ,270 & 29 & ,789 & 10000 &, 37068 & -65813 & 85813 \\
\hline & $\begin{array}{l}\text { Equal variances } \\
\text { not assumed }\end{array}$ & & & ,273 & 26,945 & ,787 & 10000 &, 36651 & -65209 & 85209 \\
\hline \multirow[t]{2}{*}{ KINO } & $\begin{array}{l}\text { Equal variances } \\
\text { assumed }\end{array}$ & 263 & 612 &,- 336 & 29 & ,739 & -08079 & ,24030 &,- 57227 & ,41069 \\
\hline & $\begin{array}{l}\text { Equal variances } \\
\text { not assumed }\end{array}$ & & &,- 336 & 28,876 & ,739 &,- 08079 & ,24029 &,- 57234 & ,41076 \\
\hline
\end{tabular}

Sumber: Data diolah

\section{ANALISIS DAN PEMBAHASAN}

Dari analisis yang dilakukan dengan menggunakan SEM metode alternatif dengan partial least square (PLS), ringkasan hasil pengujian hipotesis secara simultan dapat dilihat seperti di bawah ini:

Dari hasil estimasi berdasarkan Tabel 2, Tabel 3, Tabel 4, Gambar 2, dan Tabel 5, dapat disimpulkan bahwa:

1. Semua variabel indikator untuk setiap konstruk memiliki loading factor di atas 0,5 dan signifikan pada taraf 0,05 .

2. Koefisien parameter hubungan antara Formalisasi ke Praktik MMT adalah 0,757 dan signifikan pada taraf 0,05.

3. Koefisien parameter hubungan antara Desentralisasi ke Praktik MMT adalah 0,050 dan tidak signifikan pada taraf 0,05.

4. Koefisien parameter hubungan antara Praktik MMT ke Kualitas Produk adalah 0,707 dan signifikan pada taraf 0,05.

5. Koefisien parameter hubungan antara Praktik MMT ke Kinerja Organisasi adalah 0,287 dan signifikan pada taraf 0,05.

6. Koefisien parameter hubungan antara Kualitas Produk ke Kinerja Organisasi adalah 0,575 dan signifikan pada taraf 0,05 .

7. Nilai Q-Square Predictive Relevance masing-masing sebesar 0,427 (Praktik MMT), 0,420 (Kualitas Produk), dan 0,357 (Kinerja Organisasi). Ini berarti bahwa model semuanya memiliki nilai di atas 0 , sehingga dapat disimpulkan model memiliki predictive relevance.

8. Hasil pada Tabel 5 menunjukkan bahwa tidak ada perbedaan jawaban responden antara yang merespon segera dengan yang tidak, sehingga dapat disimpulkan bahwa tidak ada bias respon.

Hasil temuan studi menyatakan bahwa formalisasi berpengaruh signifikan terhadap praktik MMT. Berdasarkan hasil tersebut, dapat disimpulkan bahwa hipotesis pertama terbukti atau didukung dengan fakta. Ini berarti bahwa organisasi yang memiliki formalisasi yang tinggi cenderung mengarahkan pada spesialisasi tinggi dan departementalisasi fungsional. Unit analisis studi ini yaitu perusahaan perlengkapan dan komponen kendaraan bermotor roda empat atau lebih di Indonesia, tentu memerlukan spesifikasi produk yang sangat ketat 
dan karenanya juga memiliki derajat spesialisasi yang tinggi. Hal ini dapat menjadi salah satu penjelas mengapa formalisasi organisasi searah dengan praktik MMT.

Hasil studi ini juga mengindikasikan bahwa semakin tinggi formalisasi, maka semakin tinggi pula praktik MMT. Ini berarti bahwa praktik MMT memerlukan kebijakan dan prosedur standar yang ketat. Hal ini dapat dijelaskan sebagai berikut.

Setiap organisasi pasti memiliki tujuan, visi, maupun misi. Setiap anggota organisasi harus mengetahuinya, memahaminya, dan saling berbagi. Ini akan dapat tercapai jika tujuan, visi, maupun misi terdeskripsi secara tertulis, dan manajemen puncak harus memiliki kekuatan untuk mempengaruhi seluruh anggota organisasi bahkan bukan anggota organisasi yang berkaitan dengan organisasi itu. Ini berarti terjadi interkoneksi antar bagian dan merupakan sebuah sistem, yang bisa berhasil jika terjalin kerjasama.

Jika dikaitkan dengan definisi MMT, yaitu kegiatan perbaikan terus menerus yang teroganisir dalam bidang kualitas, melibatkan semua orang dalam perusahaan, termasuk manajer dan karyawan, dalam upaya terpadu untuk melakukan perbaikan pada setiap tingkatan, maka jelas bahwa untuk menerapkan MMT haruslah berpikir secara sistem, dan sistem akan berhasil dengan baik jika kegiatan yang terorganisir memiliki standar prosedural secara tertulis yang baku, bukan hanya dengan anganangan atau ingatan sementara. Ini juga didukung oleh pendapat Ahire et al. (1996) yang menyatakan bahwa dalam implementasi MMT, semestinya perusahaan manufaktur memiliki ringkasan keluhan pelanggan yang diberikan pada manajer produksi secara rutin, informasi kualitas ditayangkan pada sebagian besar stasiun kerja, informasi sisa bahan harus jelas, dan informasi kemajuan kualitas harus ditunjukkan pada pabrik perusahaan yang bersangkutan.

Demikian pula perencanaan pelatihan maupun informasi tentang pemasok, yang kesemua hal di atas tentunya harus memer- lukan bentuk secara tertulis secara formal, terdokumentasi, dan tersebar ke semua bagian. Dengan demikan, makin tinggi formalisasi, maka makin terkendali pula rencana, misi, dan pekerjaan karyawan untuk searah dengan tujuan yang ingin dicapai, serta semakin tinggi pula praktik MMT.

Berdasarkan hasil evaluasi inner model seperti pada tabel 4, menghasilkan temuan bahwa desentralisasi tidak berpengaruh signifikan terhadap praktik MMT. Berdasarkan hasil tersebut, maka dapat disimpulkan bahwa hipotesis kedua ditolak atau tidak didukung dengan fakta.

Hasil studi ini memunculkan dugaan bahwa pemberian wewenang yang lebih, belum sampai ke arah kebijakan strategis karena masih tetap berada pada level manajemen puncak. Ini terlihat dari ratarata setiap indikator desentralisasi yang bernilai di bawah skala 4. Atau dengan kata lain, industri perlengkapan dan komponen kendaraan roda empat atau lebih di Indonesia memiliki tingkat diferensiasi jenis barang yang rendah dengan struktur organisasi yang masih cenderung tersentralisasi.

Hal ini terlihat dari pengambil kebijakan paling dominan dalam menentukan keputusan adalah pada tingkatan di atas manajer divisi. Organisasi yang tersentralisasi cenderung sebagai organisasi formal yaitu organisasi dimana struktur jabatan suatu organisasi yang kewenangan atau hubungan pelaporannya bersifat eksplisit dan secara formal dibentuk oleh organisasi (Hodge et al., 2003). Oleh karenanya dalam organisasi ini komunikasi dan tanggung jawab kewenangan hanya dalam satu garis departemen, tidak lintas departemen.

Hal ini bertolak belakang dengan hasil penelitian Germain dan Spears (1999) di mana hasil penelitian menyatakan bahwa berdasarkan 200 perusahaan manufaktur di Amerika ternyata tingkat desentralisasi berpengaruh positif terhadap praktik MMT. Ini berarti bahwa manajer di Amerika memberikan wewenang dalam kebijakan strategis lebih bermakna kepada level yang 
lebih rendah daripada CEO, bahkan di bawah manajer divisi (organisasi informal).

Keuntungan sebagai organisasi informal pada kecepatan beradaptasi dari perubahan lingkungan yang sangat cepat, namun hal ini sangat tergantung dengan keputusan dari decision maker dengan memperhatikan sejumlah pertimbangan seperti perbedaan individu, keterbatasan organisasi, dan perbedaan budaya.

Pemaksaan perubahan suatu organisasi dari organisasi formal ke organisasi informal tanpa kesiapan organisasi itu sendiri justru akan membuat keberhasilan pelaksanaan praktik MMT akan semakin rendah dan berpotensi konflik, karena implementasi MMT memang memerlukan jangka waktu yang panjang, apalagi jika ini dikaitkan dengan budaya suatu bangsa. Pada industri perlengkapan dan komponen dalam negeri, tampaknya masih ada kekhawatiran pendelegasian wewenang secara terdesentralisasi.

Kebijakan untuk memberikan wewenang kepada level lebih rendah dalam hal kebijakan strategis memang akan berdampak besar dan luas pada operasional perusahaan secara keseluruhan. Jika dominasi kebijakan ini dilaksanakan oleh level-level yang lebih rendah misalnya di bawah manajer divisi tanpa adanya koordinasi dan komunikasi antar departemen, maka dikhawatirkan akan menciptakan masalah yang tidak sederhana, seperti terjadi over supply, kelangkaan sumberdaya, miskomunikasi, dan berpotensi terjadinya konflik antar departemen. Hal ini bisa terjadi karena manajer setiap level dapat membuat kewenangannya sendiri-sendiri, perencanaan dan koordinasi menjadi lebih sulit, dan manajemen puncak akan kehilangan kendali dalam proses pengambilan keputusan.

Masalah-masalah yang bersifat operasional di level lini produksi memang lebih banyak diketahui oleh manajemen level bawah, namun jika pemberian wewenang yang lebih diberikan untuk hal-hal yang bersifat strategis, maka harus ada koor- dinasi yang solid antar departemen khususnya pada level manajemen atas, karena terkait dengan keterbatasan sumber daya yang dimiliki perusahaan, baik dalam hal finansial, sumberdaya (baik sumberdaya alam maupun manusia), dan teknologi. Hasil studi ini ternyata menolak studi Germain dan Spears (1999) dan Parncharoen et al. (2003).

Hasil temuan juga menyimpulkan bahwa hipotesis ketiga terbukti atau didukung dengan fakta. Hal ini menunjukkan bahwa terdapat pengaruh signifikan yang positif dari Praktik MMT terhadap kualitas produk. Hasil temuan mengindikasikan bahwa Praktik MMT yang merupakan soft technology memiliki peran yang sangat kritis dalam manajemen sumberdaya manusia untuk meraih kualitas produk akhir yang unggul. Komitmen manajemen puncak, berfungsi sebagai pengendali impelementasi MMT, tampaknya mampu menciptakan nilai-nilai yang pada akhirnya terjadi perubahan budaya organisasi, mengarahkan pencapaian tujuan, dan mengoordinasikan semua aktifitas dalam sistem, sehingga mampu memuaskan harapan pelanggan bahkan melebihinya.

Lebih lanjut, hasil temuan mengindikasikan bahwa manajemen puncak mampu menerjemahkan misi dan nilai-nilai ke dalam strategi selama tahap manufaktur, mulai pra manufaktur (Manajemen Kualitas Pemasok, Fokus terhadap Pelanggan), pada saat manufaktur (Fokus terhadap Pelanggan, Pemberdayaan Karyawan, Pelatihan Karyawan, Manajemen Proses, Penghargaan akan Peningkatan Kualitas), dan pasca manufaktur (Fokus terhadap Pelanggan).

Berdasarkan tabel 4, dapat disimpulkan bahwa hipotesis keempat diterima atau didukung dengan fakta. Hal ini menunjukkan bahwa terdapat pengaruh signifikan yang positif dari Kualitas Produk terhadap Kinerja Organisasi. Ini berarti bahwa praktik MMT tidak serta merta mampu meraih kinerja yang tinggi tanpa melalui kualitas produk yang tinggi. Artinya, karena produk 
adalah merupakan hasil akhir dari proses produksi, maka sejumlah upaya yang komprehensif dilakukan untuk mencapai produk yang berkualitas tinggi.

Dengan demikian, jika produk berkualitas tinggi maka kinerja produk (berupa karakteristik produk, termasuk tampilan produk itu sendiri, dalam hal berat, ukuran, bentuk, warna, dan kinerja fungsional), reliabilitas produk (kehandalan produk dalam hal kemungkinan bahwa produk itu mampu dioperasikan dengan baik dalam kondisi tertentu), tingkat kesesuaian dalam spesifikasi teknik produk (karakteristik operasional dan desain produk sesuai dengan standar yang ditetapkan), serta ketahanan produk (kemampuan produk untuk terus digunakan sebelum produk itu menjadi rusak atau digantikan produk baru), akan sesuai dengan harapan pelanggan. Namun pencapaian kualitas produk ini diperoleh setelah melalui proses yang panjang sebelumnya, antara lain melalui implementasi MMT.

Hasil temuan ini ternyata mendukung temuan dari Fynes dan Voss (2002), yang menyatakan bahwa salah satu indikator kualitas produk yaitu konformansi produk berpengaruh secara tidak langsung terhadap kepuasan konsumen sebagai salah satu indikator Kinerja Organisasi melalui biaya produk. Hasil temuan studi ini juga mendukung apa yang disampaikan oleh Evans dan Jack (2003) di mana hasil penelitiannya menyatakan bahwa Kualitas Produk berpengaruh signifikan dan positif terhadap dua indikator dari Kinerja Organisasi, yaitu kepuasan konsumen dan kinerja keuangan.

Berdasarkan tabel 4, studi ini menghasilkan temuan bahwa Praktik MMT berpengaruh signifikan terhadap Kinerja Organisasi. Ini berarti bahwa implementasi praktik MMT ternyata mampu memberikan efek yang positif baik dari sisi manusianya maupun teknikalnya. Keberhasilan manajemen puncak dalam menerjemahkan visi dan misi terutama yang terkait dengan peningkatan kualitas sampai tingkat lini produksi, seperti dukungan sumber daya, identifikasi tu- juan yang jelas, serta membudayakan pentingnya kualitas mampu mensinergikan kekuatan yang ada, menumbuhkan rasa memiliki dan suasana yang kondusif, yang pada akhirnya memotivasi karyawan dalam berkarya dan selalu belajar.

Pengendalian kualitas produk sejak awal mulai dari pemilihan bahan baku, proses produksi, sampai ke tangan konsumen akan menjamin produk berkualitas yang memiliki tingkat kegagalan rendah. Lebihlebih dengan adanya delegasi wewenang di tingkat lini produksi yang tentu akan mempercepat penyelesaikan masalah. Ini akan berakibat pada rendahnya produk cacat, mengurangi waktu rework yang tentu akan menurunkan waktu siklus, sehingga kecepatan pengiriman menjadi lebih baik. Demikian pula orientasi pada pasar atau pelanggan yang selalu terus dijalankan akan selalu menyebabkan perusahaan mencari cara berproduksi dan memenuhi harapan pelanggan dengan lebih baik.

Secara umum dapat disimpulkan bahwa praktik MMT terbukti berpengaruh terhadap pencapaian kualitas produk yang tinggi, kecepatan pengiriman, kemudahan menyesuaikan terhadap perubahan volume produksi dan persediaan, penurunan waktu siklus, kualitas proses produksi, kepuasan konsumen, kepuasan karyawan, serta pangsa pasar yang lebih tinggi. Hasil temuan yang menyatakan bahwa Praktik MMT berpengaruh secara signifikan dan positif terhadap kinerja keuangan atau kinerja organisasi, mendukung apa yang disampaikan oleh Costa dan Lorente (2004a, 2004b).

\section{SIMPULAN DAN SARAN \\ Simpulan}

Temuan secara empiris tentang pengaruh formalisasi sebagai komponen stuktur organisasi terhadap praktik manajemen mutu mendukung temuan Germain dan Spears (1999) dan Parncharoen et al. (2003). Ini berarti bahwa praktik MMT memerlukan kebijakan dan prosedur standar yang ketat. Makin tinggi tingkat formalisasi, makin tinggi pula tingkat praktik MMT. Makin 
terkendali rencana, misi, dan pekerjaan karyawan untuk searah dengan tujuan yang ingin dicapai, maka semakin berpengaruh positif terhadap keberhasilan praktik MMT.

Temuan secara empiris tentang pengaruh desentralisasi sebagai komponen stuktur organisasi terhadap praktik MMT menolak temuan Germain dan Spears (1999). Ini berarti bahwa pemberian wewenang belum sampai ke arah kebijakan strategis, yaitu dalam hal: barang apa yang diproduksi/ dipabrikasi, penentuan lokasi pabrik, penentuan jumlah gudang penyimpanan, serta penentuan lokasi gudang penyimpanan, karena ada kekhawatiran bahwa pendelegasian wewenang secara terdesentralisasi akan menciptakan potensi masalah seperti terjadi over supply, kelangkaan sumberdaya, miskomunikasi, dan terjadinya konflik antar departemen. Hal ini bisa terjadi karena manajer setiap level dapat membuat kewenangannya sendiri-sendiri, perencanaan dan koordinasi menjadi lebih sulit, dan manajemen puncak akan kehilangan kendali dalam proses pengambilan keputusan.

Temuan secara empiris mengungkapkan bahwa industri perlengkapan dan komponen kendaraan roda empat atau lebih di Indonesia memiliki karakteristik mechanistic structure, yaitu struktur yang tersentralisasi dengan tingkat formalisasi tinggi dan spesialisasi tinggi pada departementalisasi fungsional. Akan tetapi, meskipun dengan tingkat formalisasi yang tinggi tidak berarti bahwa pengetahuan ataupun penguasaan teknologi yang digunakan juga tinggi.

Temuan secara empiris tentang pengaruh praktik MMT terhadap kualitas produk memperkuat hasil temuan Ahire et al. (1996) dan Prajogo dan Brown (2004). Ini berarti bahwa manajemen puncak mampu menerjemahkan misi dan nilai-nilai ke dalam strategi selama tahap manufaktur, mulai pra manufaktur (Manajemen Mutu Pemasok, Fokus terhadap Pelanggan), pada saat manufaktur (Fokus terhadap Pelanggan, Pemberdayaan Karyawan, Pelatihan Karyawan, Manajemen Proses, Penghargaan akan
Peningkatan Kualitas), dan pasca manufaktur (Fokus terhadap Pelanggan).

Temuan secara empiris tentang pengaruh kualitas produk terhadap kinerja organisasi memperkuat hasil temuan Fynes dan Voss (2002) serta Evans dan Jack (2003). Hasil studi Fynes dan Voss (2002) menunjukkan bahwa konformansi produk berpengaruh terhadap kepuasan konsumen, sedangkan Evans dan Jack (2003) mengungkapkan bahwa Kualitas Produk berpengaruh signifikan dan positif terhadap kepuasan konsumen dan kinerja keuangan.

Temuan secara empiris tentang pengaruh praktik MMT terhadap kinerja organisasi memperkuat hasil temuan Costa dan Lorente (2004a, 2004b). Ini berarti bahwa implementasi praktik MMT ternyata mampu memberikan efek yang positif baik dari sisi manusianya maupun teknikalnya.

Temuan secara empiris mengungkapkan bahwa praktik MMT tidak serta merta mampu meraih kinerja yang tinggi tanpa melalui pencapaian kualitas produk yang tinggi. Artinya, karena produk adalah merupakan hasil akhir dari proses produksi, maka sejumlah upaya yang komprehensif dilakukan untuk mencapai produk yang berkualitas tinggi, salah satunya melalui praktik MMT.

\section{Saran}

Bagi industri perlengkapan dan komponen kendaraan roda empat atau lebih di Indonesia yang memiliki karakteristik mechanistic structure, manajer level menengah dan puncak diharapkan lebih sering turun ke gemba (bengkel kerja) untuk lebih memahami persoalan dengan lebih mendasar. Diharapkan pula untuk kebijakankebijakan strategis agar lebih melibatkan manajer pada level di bawah manajemen puncak dan beralih dari manajemen keluarga menjadi manajemen yang lebih modern dengan mengedepankan profesionalisme. Studi ini dilakukan terhadap 31 dari 162 perusahaan perlengkapan dan komponen kendaraan roda empat atau lebih di 
Indonesia. Keengganan pelaku usaha dalam memberikan respon atas penelitian ini tentu memunculkan keterbatasan studi yang perlu ditindaklanjuti dengan penelitian di masa mendatang dengan lebih banyak melibatkan subyek penelitian. Selain itu, riset lanjutan yang bisa dikembangkan adalah dengan membandingkan model hasil temuan ini terhadap status kepemilikan, misalnya perusahaan dalam negeri dibandingkan kepemilikan asing, mengingat gaya kepemimpinan dengan budaya yang berbeda bisa saja mempengaruhi implementasi manajemen mutu terpadu serta desain organisasinya, sehingga memiliki dampak terhadap kualitas produk dan kinerja perusahaan (organisasi).

\section{DAFTAR PUSTAKA}

Ahire, S. L., D. Y. Golhar, dan M. A.Waller. 1996. Development and Validation of TQM Implementation Constructs. Journal of Decision Sciences 27(1): 23-56.

BPS Provinsi Jawa Timur. 2004. Jawa Timur dalam Angka: East Java in Figures 2003. CV Mitra Guna Bahagia. Surabaya.

Brah, S. A., S. S. L. Tee, dan B. M. Rhao. 2002. Relationship between TQM and Performance of Singapore Company. International Journal of Quality dan Reliability Management 19(4): 356-379.

Claycomb, C., C. Droge, dan R. Germain. 2002. Applied Product Quality, Knowledge and Performance, Moderating Effects of Uncertainty. International Journal of Quality dan Reliability Management 19(6): 649-671.

Costa, M. M. dan A. R. Martínez. 2004a. Comparison of TQM and ISO 9000 Effects in Company Performance: An Empirical Study in Spanish Companies. Second World Conference on POM dan $15^{\text {th }}$ Annual POM Conference, Cancun, Mexico April 30 -May 3. 2004b. ISO 9000 as a Tool for TQM: A Spanish Case Study. Quality Management Journal 11(4): 20-30.

Evans, J. R. dan E. P. Jack. 2003. Validating Key Results Linkages in the Baldrige
Performance Excellence Model. Quality Management Journal 10(2): 7-24.

Fynes, B. dan C. Voss. 2001. A Path Analytic Model of Quality Practice, Quality Performance, and Business Performance. Journal of Production dan Operation Management 10(4): 494-514.

2002. The Moderating Effect of Buyer-Supplier Relationship on Quality Practices and Performance. International Journal of Operation dan Production Management 22(6): 589-613. MCB University Press Emerald.

Germain, R. dan N. Spears. 1999. Quality Management and Its Relationship with Organizational Context and Design. International Journal of Quality dan Reliability Management 16(4): 371-391. MCB University Press.

Ghozali, I. 2006. Structural Equation Modeling Metode Alternatif dengan Partial Least Square PLS. Edisi Pertama. Badan Penerbit Universitas Diponegoro. Semarang.

Ghozali, I. dan Fuad. 2005. Structural Equation Modeling: Teori, Konsep dan Aplikasi dengan Program Lisrel 8.54. Edisi Pertama. Badan Penerbit Universitas Diponegoro. Semarang.

Hodge, B. J., W. P. Anthony, dan L. M. Gales. 2003. Organization Theory. $6^{\text {th }}$ ed. Pearson Education, Inc. Prentice Hall New Jersey USA.

Jabnoun, N. 2005. Organizational Structure for Customer-Oriented TQM: An Empirical Investigation. The TQM Magazine 39(3): 226-236.

Jawa Pos. 2006. Ford Bikin Pabrik di Indonesia. Senin, 22 Mei 2006.

Jones, G. R. 2004. Organizational Theory, Design dan Change: Text dan Cases. $4^{\text {th }}$ ed. Prentice Hall . New Jersey.

Kamar Dagang dan Industri Indonesia. 2007. Visi 2030 dan Roadmap 2010 Industri Nasional. http://www. kadinindonesia.or.id/berita/kadinpusa t/2007/07/323107525316/20\%E2\%80\%9 
307\%E2\%80\%93-2007.-VISI 2030-danROADMAP-2010 INDUSTRI NASIONAL. Diakses 28 Februari 2012.

Nasution, M. N. 2005. Manajemen Mutu Terpadu (Total Quality Management). Edisi Kedua. Penerbit Ghalia Indonesia, Bogor.

Parncharoen, C., A. Girardi, dan E. Lanny. 2003. The Impact of Cultural Values on the Successful Implementation of Total Quality Management: A Comparison Between the Australian and Thai Models. The Seventh International Conference on Global Business dan Economic Development. January, 8-11. Bangkok, Thailand.

Prajogo, D. I. dan A. Brown. 2004. The Relationship between TQM Practices and Quality Performance and the Role of Formal TQM Programs: An Australian Empirical Study. Quality Management Journal 11(4): 31-42.

Psychogios, A. G. dan C. V. Priporas. 2007. Understanding Total Quality Management in Context: Qualitative Research on Managers' Awareness of TQM Aspects in the Greek Service Industry. The Qualitative Report 12(1): 40-66.

Robbins, S. P. 2003. Organizational Behavior. 10th ed. Pearson Education Inc. New Jersey USA.

Rowe, K. 2006. The Measurement of Composite Variables from Multiple Indicator: Application in Quality Assurance and Accreditation SystemsChildcare. Background paper prepared for The National Childcare Accrediation
Council. August. Australian Council for Educational Research.

Shahraki, A., M. Konarizadeh, M. J. Paghaleh, dan M. Zarei. 2011. HRM Effects on TQM. Business Management Dynamics 1(3): 1-12.

Sebastianelli, R. dan N. Tamimi. 2003. Understanding the Obstacles to TQM Success. Quality Management Journal 10(3): 45-56.

Siagian, N. 2006. Kompetisi Makin Ketat Industri Komponen Lokal Terseok-seok. ekonomi/industri/2004/0811/ind1.html. Diakses tanggal 4 Maret 2008.

Sila, I. dan M. Ebrahimpour. 2002. An Investigation of The Total Quality Management Survey Based Research Published Between 1989 and 2000. International Journal of Quality dan Reliability Management 19(7): 902-970.

Sila, I. 2007. Examining The Effects of Contextual Factors on TQM and Performance Through The Lens of Organizational Theories: An Empirical Study. Journal of Operations Management, Elsvier 25: 83-109.

Thamizhmanii, S. dan S. Hasan. 2010. A Review on an Employee Empowerment in TQM Practice. Journal of Achievements in Materials dan Manufacturing Engineering 39(2): 204-210.

Wagner, C., P. P. Groenewegen, D. H. de Bakker, dan G. Van der Wal. 2001. Environmental and Organizational Determinants of Quality Management. Quality Management in Health Care 9(4): 63-76. 